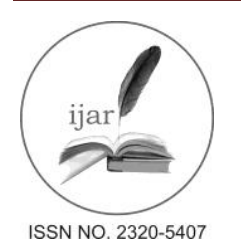

Journal homepage: http://www.journalijar.com
Journal DOI: 10.21474/IJAR01

INTERNATIONAL JOURNAL

OF ADVANCED RESEARCH

RESEARCH ARTICLE

\title{
A COMPARATIVE STUDY ON GUT MICROFLORA OF EARTHWORMS EUDRILUS EUGENIAE AND
} EISENIA FETIDA.

B.Sivasankari* and Anandharaj.M.

Department of Biology, Gandhigram Rural Institute- Deemed University, Gandhigram-624 302 Dindigul (Dt), Tamilnadu, India.

\section{Manuscript Info}

Manuscript History:

Received: 18 March 2016

Final Accepted: 26 April 2016

Published Online: May 2016

Key words:

Earthworm gut, microbes, colony

forming units

*Corresponding Author

B.Sivasankari.

\begin{abstract}
In the present study attempt was made to prepare vermicompost from the leaf materials such as Gliricidia sepium Jacq, Leucaena leucocephala (Lam.) De Wit and Cassia auriculata Linn using the earthworms, Eudrilus eugeniae (Kinberg) and Eisenia fetida (Savigny) along with cowdung in four different treatments. Fortnightly the analyses $(0,15,30,45$ and $60 \mathrm{~d})$ were done to evaluate the colony forming units (CFU) of bacteria, fungi and actinimycets in earthworm guts (fore, mid and hind gut). The results showed that the higher load of CFU of bacteria (105 \pm 1.15$)$, fungi $(100.33 \pm 1.15)$ and actinomycetes $(111.00 \pm 1.00)$ were observed in the hind gut of E.eugeniae on $60 \mathrm{~d}$ in vermicompost prepared using C.auriculata + L.leucocephala + Cowdung mixture with E.eugeniae than in fore [bacteria $(95.00 \pm 2.00)$, fungi $(91.00 \pm 1.00)$ and actinomycetes (100.67 \pm 0.58$)$ ] and mid guts [bacteria (100.00 \pm 1.00$)$, fungi $(96.00 \pm 1.00)$ and actinomycetes $(105.67 \pm 1.15)]$ and in other treatments.
\end{abstract}

Copy Right, IJAR, 2016...All rights reserved..

\section{Introduction:-}

Man knows earthworms ever since he started soiling his hand and called them as "intestines of earth". The earthworms are natural resources of fertility and life, so they are popularly called as "friends of farmers". Earthworms can serve as nature's ploughman and they form nature's gift to produce good humus by minimizing the time of humification of organic materials. Since the diversity of earthworm species varies with different soil types and different agro climatic conditions, the species suited to a particular region must be identified. The digestive tract of the earthworm is one of its unique features, being highly adapted according to its activities of burrowing and feeding. The earthworm gut is a natural bioreactor and the gizzard is a novel colloidal mill in which the feed is ground into particles smaller than one micron giving enhanced surface area for the microbial processing (Dkhar and Dkhar, 2004). The earthworm ingests soil, along with decomposing organic matter in it, which are mixed by powerful muscles and passed through its digestive tract. The digestive tract releases digestive fluids that contain enzymes which are mixed with the soil that has been ingested. The digestive fluids help in releasing sugars, amino acids and smaller sized organic molecules. These molecules are then absorbed via the membrane of the intestine, and used for energy and the synthesis of new cells. The earthworm gut provides a suitable place for the growth of bacterial colonies and this is evidence for the fact that earthworm castings contain significant number of bacteria that is present in the surrounding soil. The digested material is passed out through the anus in the form of castings. However, a better understanding of nutrient cycling and the factors governing their decomposition in soil is imperative for implementing sustainable management practices. Nutrient cycling in soil involves chemical, biochemical and physico-chemical reactions, with the biochemical reactions being catalyzed by soil enzymes associated with viable cells of microbial origin and plant roots. Therefore, any factor that affects soil microbial population will necessarily alter soil enzyme activity (Kiss et al., 1975). The whole world depends only on farmers for daily food. About 70 percent of the economy depends on agriculture only. Farmers regard earthworms as their friends and hold them in the high esteem as nature's ploughman (Darwin, 1881). It is a well proved fact that 
earthworms influence soil structure, decompose organic materials, recycle nutrients present in the soil through physical participation by feeding, fragmentation, aeration, turnover and dispersion; through chemical participation by digesting the organic substrates and by contributing nutrients to the soil through their metabolic by-products and dead tissues; and, through biological participation by providing shelter to the beneficial microbes in their gut and by activating soil microbial activity through the excretion of castings (Daniel and Karmegam, 2000 and Mahalingam and Daniel, 2008-a).

\section{Methods:-}

Vermicompost preparation:-

In the present study epigeic earthworms, Eudrilus eugeniae (Kinberg) and Eisenia fetida (Savigny) were collected from the breeding stock of the Department of Biology, Gandhigram Rural Institute-Deemed University, Gandhigram, Tamilnadu, India and leaf materials of Gliricidia sepium Jacq, Leucaena lucocephala (Lam.) De Wit and Cassia auriculata Linn were collected from Gandhigram campus. The leaf materials were separately subjected to predigestion for 15 days by sprinkling water on the heap and covering it with gunny bag and turning it periodically in order to release out the initial heat produced during decomposition of organic material. The changes in temperature was observed every three days. The vermibeds were prepared in plastic containers of $45 \times 35 \times 15 \mathrm{~cm}$ size and the substrate was moistened to hold 60-80 percent moisture and kept for 24 hours stabilization. 20 numbers of healthy clitellate E. eugeniae and 30 numbers of E. fetida were separately introduced in the vermibeds. The vermicomposting trials were carried out in the rearing room with the relative humidity and the temperature of 75-85 percent and $26-28^{\circ} \mathrm{C}$ respectively. The substrate was turned (mixed) once in a week and maintained up to 60 days. The experiment was carried out with three replicates for each substrate with proper control. (Daniel and Karmegam, 2000).

\section{Microbial study:-}

The total microbial counts in terms of colony forming units (CFU) of bacteria fungi and actinomycetes in the earthworm (fore, mid and hind) guts were determined every 15 days $(0,15,30,45$ and $60 \mathrm{~d})$ using standard plate count method (Parthasarathi and Ranganathan, 1998; Nagarathinam et al., 2000).

\section{Statistical Analysis:-}

The following statistical tools were used for the analyses and interpretation of the data. The experimental results are presented in the form of graphs using Microsoft Excel (Version 2003 and 2007). Mean and Standard Deviation were also calculated with the help of the same tool.

\section{Results and Discussion:-}

The results on the observation of total CFU of bacteria, fungi and actinomycetes in the fore gut of E.eugeniae and

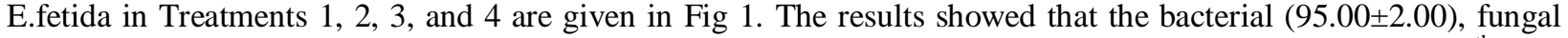
$(91.00 \pm 1.00)$ and actinomycetes $(100.67 \pm 0.58)$ count was higher in fore gut of E.eugeniae i.e in $\mathrm{T} 3$ on $60^{\text {th }}$ day compared to T1 bacteria $(90.00 \pm 3.00)$, fungi $(85.67 \pm 0.58)$ and actinomycetes $(95.00 \pm 1.73)$, T2 bacteria (84.67 \pm 0.58$)$, fungi $(81.00 \pm 1.00)$ and actinomycetes $(90.67 \pm 1.53)$, and $\mathrm{T} 4$ bacteria $(90.00 \pm 3.00)$, fungi $(85.67 \pm 0.58)$ and actinomycetes $(95.33 \pm 1.15)$. 
Fig 1:- Total colony forming units of bacteria, fungi and actinomycetes observed in the fore gut of Eudrilus eugeniae and Eisenia fetida in Treatments 1, 2,3 and 4

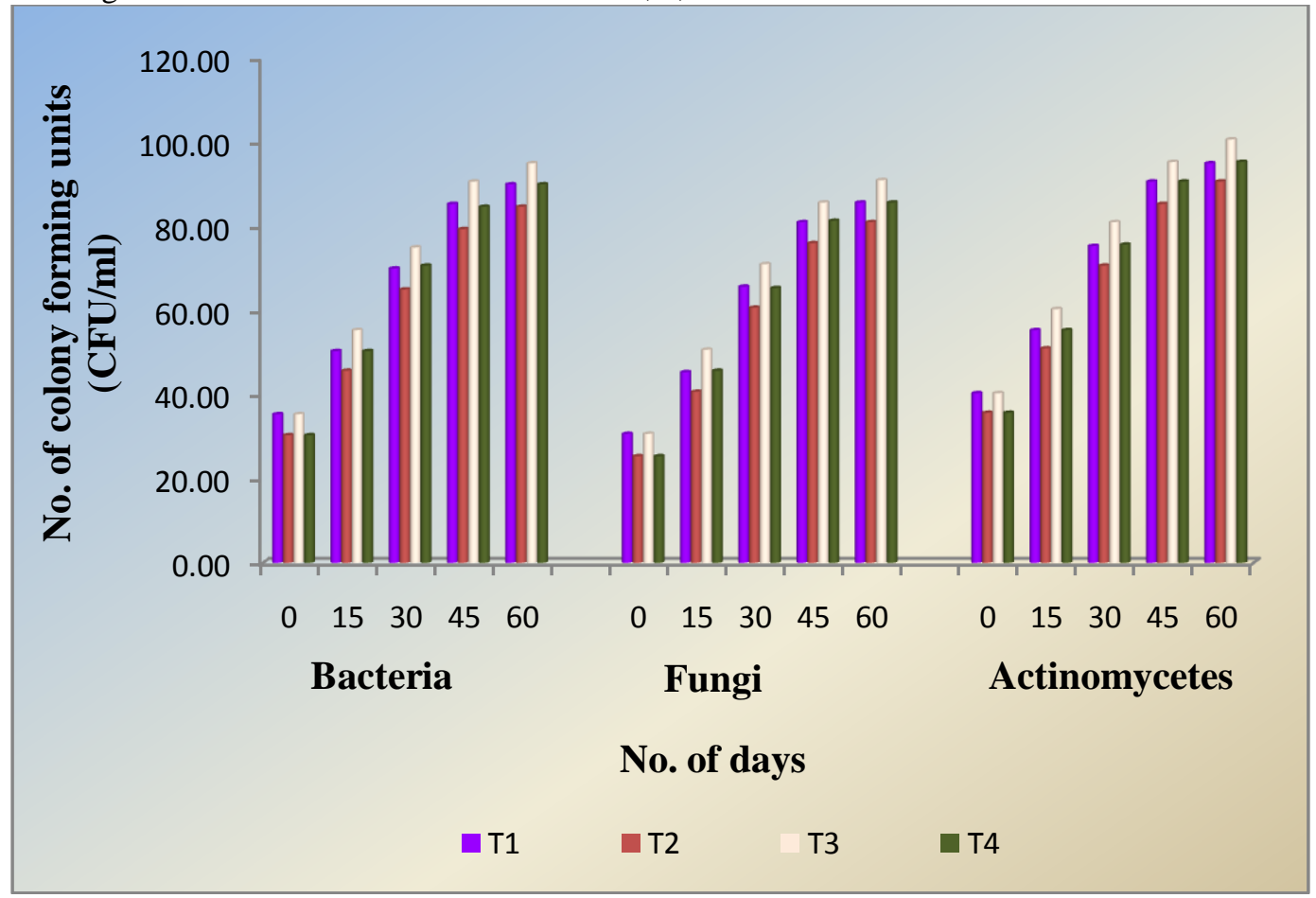

T1 - G.sepium + L.leucocephala + Cowdung (1:1:2) + E.eugeniae

$\mathrm{T} 2$ - G.sepium + L.leucocephala + Cowdung $(1: 1: 2)+$ E.fetida

T3 - C.auriculata + L.leucocephala + Cowdung $(1: 1: 2)+$ E.eugeniae

T4 - C.auriculata + L.leucocephala + Cowdung $(1: 1: 2)+$ E.fetida

Microorganisms are able to perform many chemical transformation during the decomposition of organic materials but their activity is highly dependent on other macro organisms with whom they are constantly in contact. Free soil microorganisms find suitable conditions for their activity in the anterior part of the earthworm gut as well as in worm casts. Ingestion and passage through the intestine of earthworms also affect microorganisms that are associated with plant material. It has also been suggested that microorganisms provide a source of nutrients for earthworms, with fungi as a major and bacteria as a minor source (Edwards and Fletcher, 1988). Filamentous fungi have been shown to be digested by earthworms, although report from other studies showed that the numbers of fungi in the cast after passage through the intestine (Kristufek et al., 1992) were increased. The joint action of earthworms and microorganisms characterizes the bio-oxidation of the organic material in the vermicomposting. The stimulation of the metabolic activity of the microorganisms, either living free and/or associated with the earthworm gut, and a concominant exponential increase of the total biomass of earthworms characterize the mesophilic hydrolytic stage (Benitez et al., 1999). Therefore microorganisms are mainly responsible for the biochemical degradation of the organic matter during composting and vermicomposting processes and, in the latter, earthworms play a very important role in both microbial activity and in diversity. The vermicompost is an aerobically degraded organic matter, which has undergone chemical disintegration by the enzymic activity in the gut of earthworms and also of enzymes of the associated microbial population. (Anand et al., 1995 and Kumar et al., 2010 ).

The results on the observation of total CFU of bacteria, fungi and actinomycetes in the mid gut of E.eugeniae and E.fetida in Treatments 1, 2, 3, and 4 are given in Fig 2. The results showed that the bacterial (100.00 \pm 1.00$)$, fungal $(96.00 \pm 1.00)$ and actinomycetes $(105.67 \pm 1.15)$ count was higher in mid gut of E.eugeniae i.e in T3 on $60^{\text {th }}$ day compared to $\mathrm{T} 1$ bacteria $(95.33 \pm 1.53)$, fungi $(91.00 \pm 1.00)$ and actinomycetes $(101.00 \pm 1.00)$, T2 bacteria (90.33 \pm 0.58$)$, fungi $(86.00 \pm 1.00)$ and actinomycetes $(96.00 \pm 0.00)$ and $\mathrm{T} 4$ bacteria $(95.67 \pm 1.53)$, fungi $(91.33 \pm 1.53)$ and actinomycetes $(100.33 \pm 1.15)$. 
Fig 2:- Total colony forming units of bacteria, fungi and actinomycetes observed in the mid gut of Eudrilus eugeniae and Eisenia fetida in Treatments 1, 2, 3 and 4

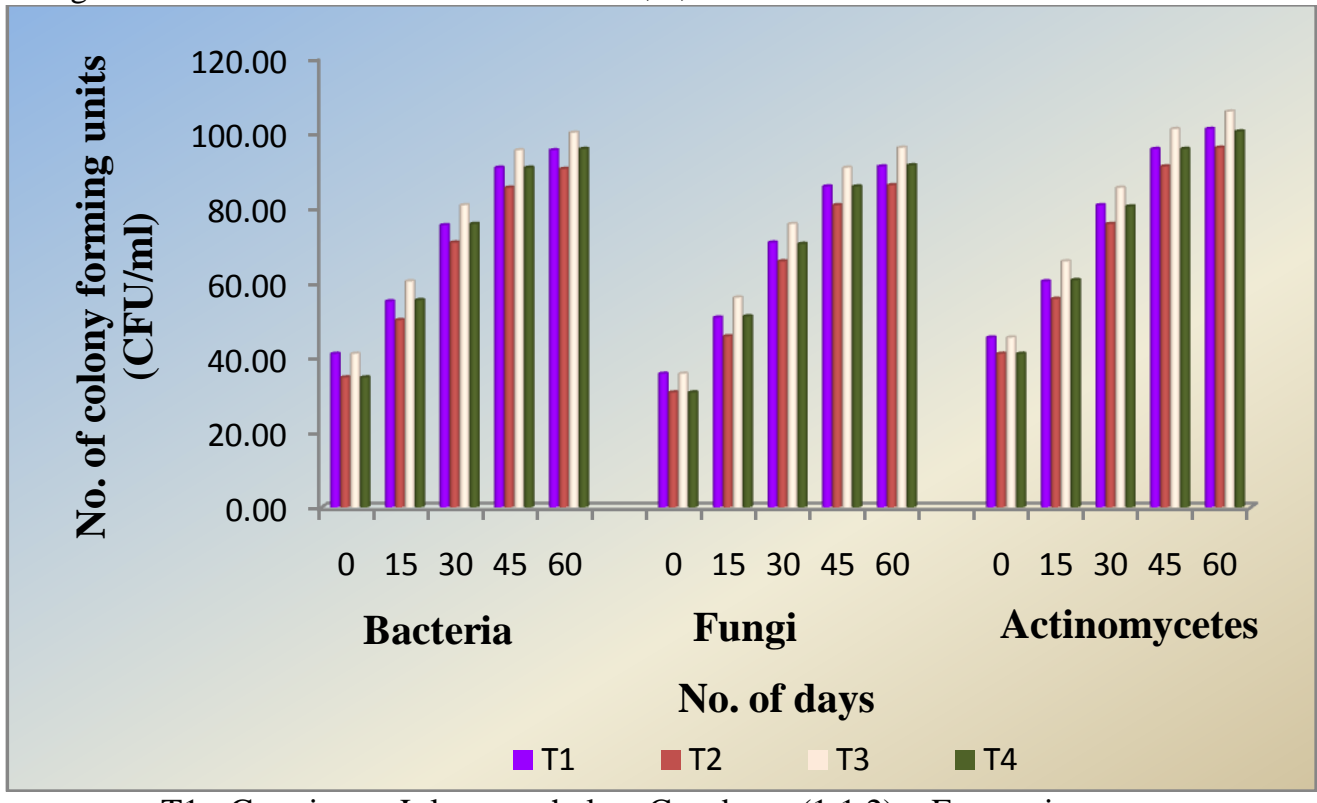

T1 - G.sepium + L.leucocephala + Cowdung (1:1:2) + E.eugeniae.

T2 - G.sepium + L.leucocephala + Cowdung (1:1:2) + E.fetida.

$\mathrm{T} 3$ - C.auriculata + L.leucocephala + Cowdung $(1: 1: 2)+$ E.eugeniae.

T4 - C.auriculata + L.leucocephala + Cowdung (1:1:2) + E.fetida.

The gut microflora of the earthworms belong to bacterial colonies of Acromobacter, Micrococci and Bacillus and the fungal colonies of Aspergillus fumigatus, Aspergillus flavus and Penicillium rubrum. Edwards and Fletcher (1988) described the fungi and bacteria to be important nutrients for the earthworms. Gut transit time may be one of the most important factors determining microbial population growth in worm guts and is highly variable between different species and is dependent on factors like food quality (Hendriksen, 1991) and temperature (Barois and Lavelle, 1986). In earthworms with short gut transit times, there is probably not enough time for microbial multiplication. Whereas in earthworms with longer gut transit time, there may be enough time for microbial multiplication since these earthworms tend to feed on organic rich materials, where microbial colonization is already high (Kristufek et al., 1992).

The results on the observation of total CFU of bacteria, fungi and actinomycetes in the hind gut of E.eugeniae and E.fetida in Treatments 1, 2, 3, and 4 are given in Fig 3. The results showed that the bacteria (105.33 \pm 1.15$)$, fungal $(100.33 \pm 1.15)$ and actinomycetes $(111.00 \pm 1.00)$ count was higher in mid gut of E.eugeniae i.e in $\mathrm{T} 3$ on $60^{\text {th }}$ day compared to $\mathrm{T} 1$ bacteria $(100.00 \pm 1.00)$, fungi $(95.33 \pm 1.15)$ and actinomycetes $(105.67 \pm 1.15)$, T2 bacteria $(95.33 \pm 1.15)$, fungi $(91.00 \pm 0.00)$ and actinomycetes $(100.67 \pm 1.15)$ and $\mathrm{T} 4$ bacteria (100.67 \pm 0.58$)$, fungi

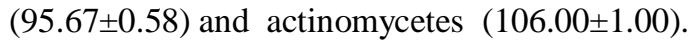


Fig 3:- Total colony forming units of bacteria, fungi and actinomycetes observed in the hind gut of Eudrilus eugeniae and Eisenia fetida in Treatments 1, 2, 3 and 4

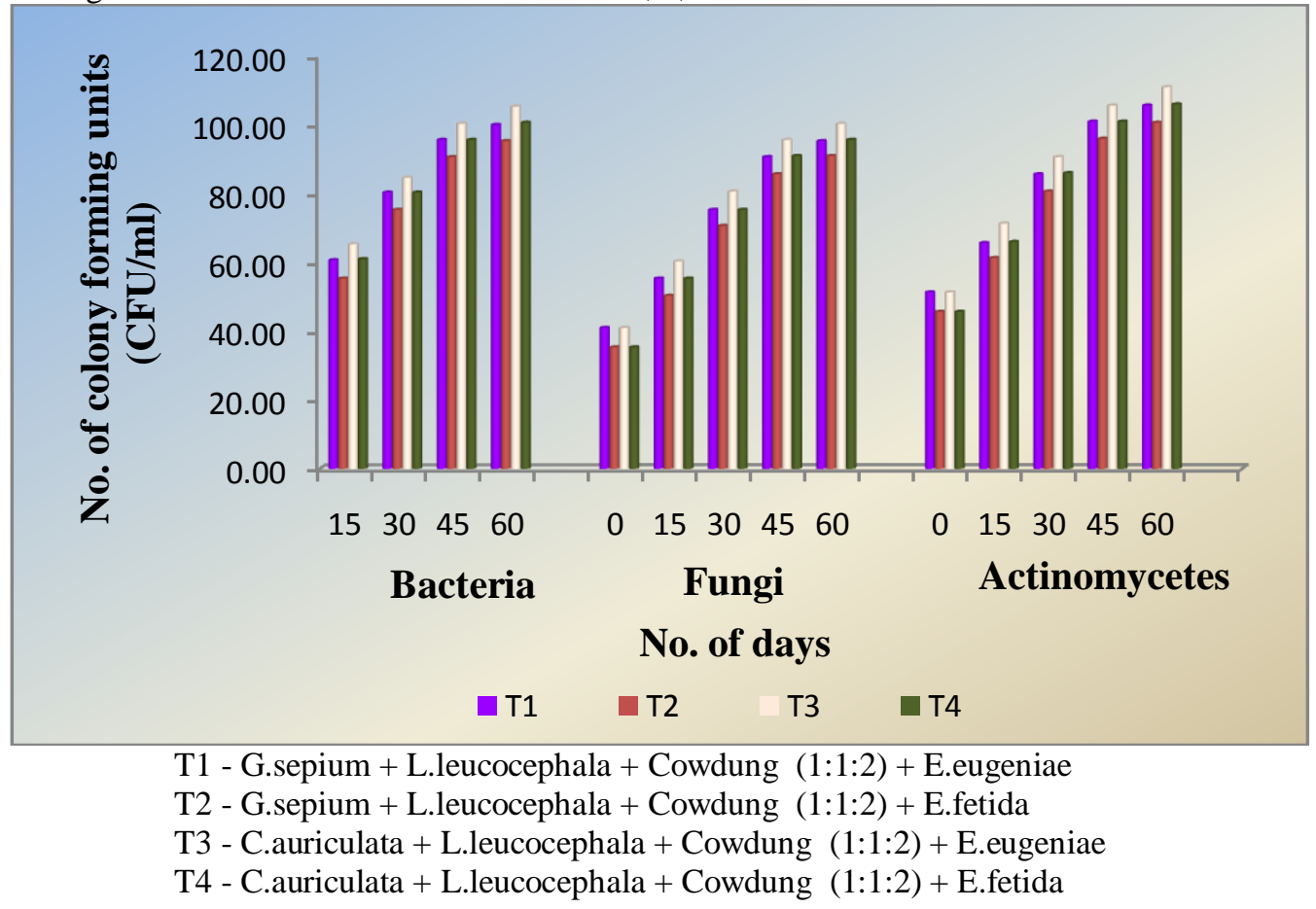

Highest load of bacteria fungi and actinomycetes were observed in the hind gut of E.eugeniae on $60 \mathrm{~d}$ in vermicompost prepared using C.auriculata + L.leucocephala + Cowdung mixture with E.eugeniae was observed in T3 (Figs 3). In studies carried out by other authors (Karmegam and Daniel 2000-b and Singh and Sharma, 2002), they have reported that the microorganisms are stimulated during the passage through the gut of the earthworms where, water and soluble- $\mathrm{C}$ in the form of intestinal mucus produced by the earthworms awaken the dormant micro flora, thereby increase the decomposition of the stable forms of the organic matter and release the nutrients which in turn increase the soil fertility. Vermicompost and vermicast are very good sources for enriching the soil microflora. In the vermicasts the CFU of actinomycetes was significantly higher than that of bacteria and fungi. Edwards and Fletcher (1988) have observed an increased bacterial number from fore to hindgut and decreased amount of leaf material from fore-to hindgut in their studies. It has been speculated that the increase of bacterial numbers towards the end of the earthworm gut could be due to growth of bacterial cells or to an activation of dormant cells during gut passage (Kristufek et al., 1992). Filamentous fungi were detected in larger amounts only in the foregut of the earthworms and latter they disappeared because they were digested during passage through the crop and gizzard of the earthworms. However the spores of fungi which survive after gut passage will multiply in the mid and hind gut. Such results have been observed by Schonholzer et al (2002). However the bacterial population increased during the gut passage and they were found in higher number in fresh cast when compared to the fore gut. Nagarathinam et al (2000) and Karmegam and Daniel (2000-b) described that the alimentary canal of the earthworm carries great numbers of bacteria, fungi and actinomycetes. The major source of nutrients for earthworms is microorganisms and the earthworms promote microbial activity during the decomposition of organic matter. The process by which the microbes benefit from the mucus secretions of the earthworm and the process by which the earthworms benefit from the enhanced microbial decomposition of ingested organic matter make their relationship mutually symbiotic.

\section{Conclusion:-}

The studies carried out on microbial CFU of bacteria, fungi and actinomycetes in earthworms, E.eugeniae and E.fetida in the fore, mid and hind gut showed a higher load in the hind gut than in the fore gut and mid gut. In the present study increased bacterial, fungal and actinomycetes number from fore to hindgut were observed. It has been speculated that the increase of bacterial, fungal and actinomycetes numbers towards the end of the earthworm gut could be due to growth of bacterial, fungal and actinomycetes cells or to an activation of dormant cells during gut passage. The microorganisms are stimulated during the passage through the gut of the earthworms where, water and soluble- $\mathrm{C}$ in the form of intestinal mucus produced by the earthworms awaken the dormant micro flora, thereby 
increase the decomposition of the stable forms of the organic matter and release the nutrients which in turn increase the soil fertility.

\section{References:-}

1. Dkhar, D.N. and Dkhar, M.S. 2004. Decomposition of pine needles by the Earthworm Drawida papillifer in laboratory condition. Asian J. Microbiol. Biotech. Environ. Sci. 6:521-524.

2. Kiss, S., Bularda, D.M. and Radulescu, D. 1975. Biological significance of enzymes accumulated in soil. Advances in Agronomy. 27:25-27.

3. Darwin, C. 1881. The formation of Vegetable mould through the action of worms with observations on their habits Faber and Faber Ltd, London. Pp. 9-153.

4. Daniel, T. and Karmegam, N. 2000. Bio-conversion of selected leaf litters using an African epigeic Earthworm, Eudrilus eugeniae. Ecol.Env. and Cons. 5 (3):273-277.

5. Mahalingam, P.U. and Daniel, T. 2008-a. Gut microflora of earthworm, Eisenia fetida, Environment and Ecology. 26(1A):297-299

6. Sudha, B. and Chandini, S. 2003. Vermicompost-A potential organic manure for rice, Intensive Agriculture. Pp .18 .

7. Kladivko, E.J. and Timmenga, H.J. 1990. Earthworms and agricultural management. In: Box, J.E. Hommand, L.C. (Ed.), Rhizosphere Dynamics. West View Press, Boulder. Pp. 192-216.

8. Lee, K.E. 1985. Earthworms: their Ecology and Relationships with Soils and Land Use. CSIRO, Sydney. Pp. 411.

9. Sharma, S., Pradhan, K., Satan,S. and Vasudevan, P. 2005. Potentiality of earthworms for waste management and in their uses a review. J.AM. Sci. 1(1).

10. Parthasarathi, K. and Ranganathan, L.S. 1998. Pressmud vermicasts the "hot spots" of fungi and bacteria. Ecol.Environ.Conser. 4:81-86.

11. Nagarathinam, B., Karmegam, N. and Daniel, T. 2000. Microbial changes in some organic materials subjected to earthworm action. J.Ecobiol. 12(1):45-48.

12. Edwards, C.A. and Fletcher, K.E. 1988. Interactions between earthworms and microorganisms in organicmatter breakdown. Agric.Ecosyst.Environ. 24:235-247.

13. Kristufek, V., Ravasz, K. and Pizl, V. 1992. Changes in densities of bacteria and microfungi during gut transit in Lumbricus rubellus and Aporrectodea caliginosa (Oligochaeta:Lumbricidae). Soil Biol.Biochem. 24:14991500 .

14. Benitez, E., Nogales, R., Elvira, C., Maciandaro, G. and Celccanti, B. 1999. Enzyme activities as indicator of the stabilization of sewage sludge composting with Eisenia fetida. Bioresource Technology. 67:297-303.

15. Anand, J.A., Wilson, M.D.P. and Kale, R.D. 1995. Effect of vermiwash on seed germination and seedling growth. J. Soil Biol.Ecol. 15:90-95.

16. Kumar, R., Singh, B.L., Kumar, U., Verma, D. and Shweta. 2010. Drawida willsi Michalsen activates cellulolysis in pressmud vermireactor. Bioresource Technology. 101:9086-9091.

17. Hendriksen, N.B.1991. Gut load and food-retention time in the earthworms Lumbricus festivus and Lumbricus cataneus. A field study. Biol.Fertil.Soils. 11:170-173.

18. Barois, I. and Lavelle, P. 1986. Changes in respiration rate and some physicochemical properties of a tropical soil during transit through Pentoscolex corethrurus (Glossoscolecidae, Oligochaeta). Soil Biol. Biochem. 18: 539-541.

19. Karmegam, N. and Daniel, T. 2000-b. Selected physico-chemical characteristics and microbial population of the casts of earthworm, Pontosiolus corethrurus (Muller) and surrounding soil in on undisturbed forest floor in Sirumalai hills South India. Asian J.Microbiol.Biotech. \& Env.Sci. 2(3/4):231-234.

20. Singh, A. and Sharma, S. 2002. Composting of a crop residue through treatment with, microorganisms and subsequent vermicomposting. Bioresource Technology.

85: 107-111.

21. Schonholzer, F., Hahn, D., Zardo, B. and Zeyer, J. 2002. Automated image analysis and in hybridization as tools to study bacterial populations in food resources gut and cast of Lumbricus terrestris.J.Microbiol Methods. 48:53-68. 